\title{
Manajemen Keuangan Badan Usaha Milik Desa (BUMDes) Berdasarkan SAK-ETAP
}

\author{
Mattoasi $^{1}$ \\ ${ }^{1}$ Jurusan Akuntansi, Fakultas Ekonomi, Universitas Negeri Gorontalo, Jl. Jend. Sudirman \\ No. 6 Kota Gorontalo, Gorontalo 96128, Indonesia \\ E-mail: mattoasi@ung.ac.id ${ }^{1}$
}

\section{Article History:}

Received: 05-11-2021

Revised: 011-11-2021

Accepted: 12-11-2021

Keywords: BUMDes,

Manajemen Keuangan, SAK-

ETAP; Sistem Tradisional

\begin{abstract}
:
Pengabdian ini berkaitan dengan hasil penelitian yang telah dilakukan pada Badan Usaha Milik Desa (BUMDES) Rahmat di Desa Ayumolingo Kecamatan Pulubala Kabupaten Gorontalo. Teori yang digunakan di dalam pengabdian ini didasarkan pada teori-teori manajemen keuangan khususnya pelaporan keuangan berdasarkan standar SAK-ETAP. Tujuan pengabdian untuk mengetahui model manajemen keuangan Bumdes Rahmat dan memberi bimbingan mengenai manajemen keuangan khususnya dalam pelaporan keuangan berdasarkan standar ETAP. Metode pemecahan masalah yang dilakukan diawali dengan melakukan analisis situasi Bumdes; indentifikasi masalah; menentukan tujuan kerja; rencana pemecahan masalah; pelaksanaan kegiatan dan evaluasi kegiatan dan hasil. Hasil pengabdian menunjukkan bahwa model manajemen keuangan masih bersifat tradisional dan setelah pengabdian para pengurus Bumdes telah dapat menyusun laporan keuanga berdasarkan SAK-ETAP.
\end{abstract}

\section{Pendahuluan}

Sebagai lembaga keuangan desa yang menjalankan bisnis keuangan (financial business) yang memenuhi kebutuhan usaha-usaha skala mikro yang dijalankan oleh pelaku usaha ekonomi Desa, BUMDes wajib untuk membuat laporan keuangan seluruh unit-unit usaha BUMDes setiap bulan dengan jujur dan transparan seperti yang diharapkan (Epstein \& Manzoni, 1998). Selain itu, BUMDes juga wajib memberikan laporan perkembangan unit-unit usaha BUM Desa kepada masyarakat desa melalui musyawarah desa sekurang-kurangnya dua kali dalam satu tahun agar setiap penggunaan sumber daya organisasi dapat terarah dengan baik (Knight \& Bertoneche, 2001).

Secara umum, prinsip pembukuan keuangan BUMDes tidak berbeda dengan pembukuan keuangan lembaga lain pada umumnya. BUMDes harus melakukan pencatatan atau pembukuan yang ditulis secara sistematis dari transaksi yang terjadi setiap hari (Ikatan Akuntan Indonesia (IAI), 2015). Pencatatan transaksi itu umumnya menggunakan sistem akuntansi yang fungsinya adalah untuk menyajikan informasi keuangan kepada pihak internal dan eksternal dan sebagai dasar membuat keputusan (Meigs et al., 1996). Namun demikian dari hasil obervasi awal menunjukkan bahwa model manajemen keuangan yang digunakan masih kepada sistem manajemen keuangan yang tradisional yang sekedar mencatat besaran yang diterima dan besaran yang dibelanjakan setiap bulan, termasuk BUMDes yang ada di Desa Ayumolingo 
Kecamatan Pulubala Kabupaten Gorontalo.

Alasan dilakukan pengabdian ini tentang manajemen keuangan BUMDes berdasarkan SAK-ETAP di Desa Ayumolingo Kecamatan Pulubala Kabupaten Gorontalo di sebabkan adanya suatu fenomena pada BUMDes yang telah resmi didirikan di Desa Ayumolingo Kecamatan Pulubala Kabupaten Gorontalo yang belum sepenuhnya beroperasi sesuai dengan keinginan pengelola dan masyarakat disebabkan terbatasnya modal yang dapat digunakan untuk menjadi modal usaha. Disisi yang lain pengurus BUMDes sulit untuk mendapatkan pinjaman kepada pihak lain kerana pelaporan keuangan belum di dasarkan pada standar pelaporan keuangan yang diterima secara umum. Demikain pula model pencatatan keuangan yang digunakan di Desa Ayumolingo Kecamatan Pulubala Kabupaten Gorontalo masih yang bersifat tradisional dengan sistem single entry, sehingga dalam pelaporan keuangan mereka hanya dapat memperlihatkan catatan penerimaan uang dan catatan pengeluaran uang tanpa diakhiri dengan laporan keuangan yang dapat diterima secara umum.

Hal yang sama dalam penelitian yang dilakukan oleh Ariantini et al., (2014) yang menunjukkan bahwa (1) penyajian laporan yang terdiri atas laporan neraca dan laporan sisa hasil usaha, (2) penyajian laporan keuangan yang telah disesuaikan dengan SAK-ETAP terdiri atas (a) laporan neraca; (b) laporan sisa hasil usaha; (c) laporan perubahan ekuitas; (d) laporan arus kas; dan (e) catatan atas laporan keuangan, dan (3) penerapan SAK-ETAP berimplikasi pada penurunan sisa hasil usaha KSP Lembing Sejahtera Mandiri tahun 2013 sebesar Rp 34.960.000,00 karena adanya biaya yang tidak tercatat seperti biaya honor pengurus, biaya pelatihan, biaya sosial, dan biaya pembangunan daerah kerja.

Berdasarkan kondisi tersebut, maka semua aparat desa dihadirkan dalam pelatihan ini dan diikutkan di dalam sosialisasi cara penyusunan pelaporan keuangan yang sesuai dengan standar yang berlaku umum. Dari pengabdian ini juga dilanjutkan dengan pelatihan pencatatan transaksi yang disesuaikan dengan kondisi ekonomi yang ada di Desa Ayumolingo, dan hasilnya mereka dapat menyelesaikan sampai pada tahap laporan keuangan atas bimbingan pemateri.

Pelaksanaan pengabdian ini didasari oleh beberapa sumber penlitian diantaranya Horngren \& Jr (2007) yang mengungkapkan bahwa pendirian BUMDes itu sangat penting dan pengelolaannya harus dimaksimalkan agar dapat memberi dampak kepada masyarakat terutama kepada manajemen keuangan Badan Usaha Milik Desa (BUMDes). Di dalam Standar Akuntansi Keuangan (2012) dijelaskan beberapa manajemen keuangan yang penting ialah pembuatan laporan laba rugi, laporan perubahan modal, laporan neraca yang meliputi harta, modal dan utang serta laporan arus kas (Horngren \& Jr, 2007). Hal yang sama menurut (Macey, 1998) yang diungkapkan bahwa manajemen keuangan sebagai usaha untuk dapat menyediakan uang serta menggunakan uang untuk mendapat atau juga memperoleh aktiva. Michel \& Shaked (1984) juga menyatakan bahwa manajemen keuangan merupakan suatu proses dalam kegiatan keuangan perusahaan yang berhubungan dengan upaya untuk mendapatkan dana perusahaan serta meminimalkan biaya perusahaan dan juga upaya pengelolaan keuangan suatu badan usaha atau organisasi untuk dapat mencapai tujuan keuangan yang telah ditetapkan. Dubofsky \& Varadarajan (1987) secara sederhana menyatakan bahwa manajemen keuangan merupakan hal yang sangat penting dalam setiap organisasi karena tujuannya adalah agar nilai yang dimiliki oleh perusahaan bisa maksimal dan dapat memberikan nilai tambah dari segi finansial atau asset pada perusahaan. Ruang lingkup manajemen di bidang keuangan adalah keputusan investasi, pengelolaan aset dan keputusan pendanaan. 
Selanjutnya pemerintahan desa diharapkan dapat mengatur dan mengurus kepentingan masyarakat hukum setempat berdasarkan asal usul dan istiadat, maka pemerintah desa dituntut untuk melakukan manajemen keuangan desa secara maksimal agar setiap sumber daya yang ada dikelola dengan baik agar mempunyai manfaat kepada masyarakat. Mengenai pentingnya manajemen keuangan bagi setiap organisasi dimaksudkan melakukan pengalokasian dana perusahaan secara efisien. Riyanto (2002) menyatakan bahwa secara keseluruhan aktivitas perusahaan yang berhubungan dengan usaha mendapatkan dana yang diperlukan dengan biaya yang minimal dan syarat-syarat yang paling menguntungkan beserta usaha untuk menggunakan dana tersebut seefisien mungkin manajemen terhadap fungsi-fungsi keuangan.

Hal tersebut sejalan dengan pentingnya manajemen keuangan juga sesuai dengan pendapat (Suad, 2002) yang menyatakan bahwa manajemen keuangan merupakan segala aktivitas yang berhubungan dengan perolehan, pendanaan serta pengelolaan aktiva dengan tujuan menyeluruh. Demikian juga pendapat Keown (2001) bagaimana bisnis yang diselenggarakan dapat memperoleh dana, bagaimana mereka mendapatkan dana, bagaimana penggunaan mereka serta bagaimana bisnis profit didistribusikan.

\section{Metode}

Pengabdian ini dilakukan oleh tim pengabdi dengan cara melakukan sosialisasi kepada pengelola keuangan BUMDes berdasarkan SAK-ETAP sebagai langkah awal dalam proses pendekatan agar dapat mencapai suatu tujuan. Dengan adanya pengenalan atau sosialisasi tersebut tentu akan terjalin hubungan baik yang dilandasi oleh kepentingan yang sama yaitu meningkatkan pemahaman dan kemampuan menyusun laporan keuangan BUMDes berdasarkan SAK-ETAP. Tim melakukan koordinasi dengan Kepala Desa Ayumolingo Kecamatan Pulubala Kabupaten Gorontalo untuk menanyakan apakah sosialisasi untuk penyusunan laporan keuangan BUMDes yang sangaat dibutuhkan oleh pengelola BUMDes tersebut. Salah satu hal yang sangat dibutuhkan oleh pengelola BUMDes adalah pengelolaan keuangan BUMDes berdasarkan stadar yang berlaku umum yaitu SAK-ETAP. Program sosialisasi dan pelatihan yang diberikan oleh pengelolaan keuangan BUMDes dilaksanakan di Desa Ayumolingo Kecamatan Pulubala Kabupaten Gorontalo sesuai kesepakatan pemerintah Desa. Pelaksanaan kegiatan pengabdian ini dilakukan dengan beberapa metode, yaitu:

\section{Ceramah}

Metode ini memberikan beberapa penjelasan mendalam kepada para peserta tentang peraturan dan standar dalam pengelolaan keuangan BUMDes berdasarkan SAK-ETAP. Selain itu, peserta juga diberikan pengenalan tentang berbagai macam bentuk laporan keuangan dan cara mengenal pentingnya menyusun laporan keuangan BUMDes sebagai bentuk akuntabilitas kepada masyarakat desa. Metode ceramah ini dilakukan selama 3 jam. Media yang digunakan untuk membantu kelancaran presentasi yaitu laptop dan LCD Proyektor.

\section{Tutorial}

Peserta pelatihan diberikan materi tentang tahapan-tahapan dan penyiapan dokumen untuk mempersiapkan dalam penyusunan laporan keuangan. Demikian pula, peserta juga diberikan contoh kasus serta tahapan dalam menyusun laporan keuangan berdasarkan SAKETAP. Tahap kedua ini dilakukaan selama 3 jam. Media yang mendukung dalam mempraktikan penyusunan laporan keuangan yaitu Ms. Excel. 


\section{Diskusi}

Peserta lebih banyak diberikan kesempatan untuk mendiskusikan permasalahan yang berkaitan dengan penyusunan laporan keuangan dan kesulitan yang mereka alami. Tahap ketiga ini dilakukan selama 2 jam. Media yang mendukung saat diskusi yaitu Laptop, LCD Proyektor, Whiteboard dan Spidol.

\section{Pendampingan}

Selanjutnya langkah ini merupakan hal yang sangat penting karena peserta didampingi dalam penyusunan laporan keuangan desa sampai mereka paham. Tahap keempat dilakukan selama 3 jam. Media yang sangat penting saat melaksanakan pendapingan yaitu kertas berisi contoh-contoh penyusunan laporan keuangan desa.

\section{Evaluasi}

Evaluasi pada awal kegiatan dilakukan dalam tiga tahap yakni; Mulai dari perencanaan, Proses pelaksanaan dan Evaluasi seperti gambar berikut:

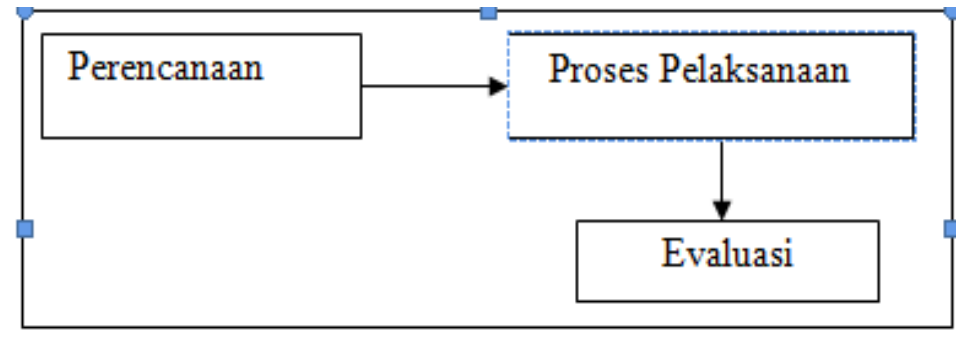

\section{Gambar 1. Evaluasi Kegiatan}

Evaluasi pada awal kegiatan dilakukan untuk menetapkan rencana kegiatan yang akan dilakukan evaluasi. Proses pelaksanaan dilakukan untuk mengetahui keterlaksanaan program. Sementara evaluasi pada akhir kegiatan dilakukan untuk mengukur tingkat keberhasilan dari keseluruhan program kegiatan dengan tema pelatihan pengelolaan keuangan Badan Usaha Milik Desa (BUMdes) berdasarkan SAK-ETAP di Desa Ayumolingo Kecamatan Pulubala Kabupaten Gorontalo.

\section{Hasil}

Pemahaman para pengelola BUMDes terhadap penyunan laporan keuangan yang sesuai dengan standar akuntansi keuangan juga sejalan dengan harapan pemerintah melalui Peraturan Pemerintah Republik Indonesia Nomor 71 Tahun 2010 tentang Standar Akuntansi Pemerintahan. Di dalam standar tersebut menyebutkan bahwa pelaporan keuangan penting bagi setiap organisasi baik skala kecil, menengah dan skala besar, sehingga dapat memahami kekayaan dan kemampuan organisasi dalam memberikan pelayanan kepada masyarakat.

\section{a. Peserta Pelatihan}

Pelatihan ini diikuti sekitar 25 orang peserta dari pengelola badan usaha milik desa (BUMDes) dan aparat desa maupun masyarakat sekitar di Desa Ayumolingo Kecamatan Pulubala Kabupaten Gorontalo. Sosialisasi tersebut dilakukan agar pengelola Badan Usaha Milik Desa (BUMDes) yang ada di Desa Ayumolingo Kecamatan Pulubala Kabupaten Gorontalo dapat dikelola dengan baik terutama dalam Pengelolaan Keuangan Badan Usaha 
Milik Desa (BUMDes) berdasarkan SAK ETAP di Desa Ayumolingo Kecamatan Pulubala Kabupaten Gorontalo Provinsi Gorontalo untuk meningkatkan transparansi dan akuntabilitas keuangan pada Badan Usaha Milik Desa (BUMDes).

Pengelolaan keuangan berdasarkan SAK ETAP tersebut memiliki manfaat sebagai media transparansi, media akuntabilitas publik, sarana informasi, serta sarana evaluasi kinerja. Sebagai media transparansi yang berguna untuk memberikan informasi keuangan yang terbuka dan jujur kepada publik berdasarkan pertimbangan bahwa publik memiliki hak untuk mengetahui secara terbuka dan menyeluruh atas pertanggungjawaban pemerintah dalam pengelolaan sumber daya yang dipercayakan maupun ketaatan terhadap peraturan perundangundangan

\section{b. Capaian Hasil Pelaksanaan}

Sosialisasi tersebut dilakukan secara langsung di Aula kantor Desa Ayumolingo Kecamatan Pulubala Kabupaten Gorontalo tentang Pengelolaan Keuangan Badan Usaha Milik Desa (BUMDes) berdasarkan SAK ETAP di Desa Ayumolingo Kecamatan Pulubala Kabupaten Gorontalo untuk meningkatkan transparansi dan akantabilitas pengelolaan keuangan pada Badan Usaha Milik Desa (BUMDes). dengan adanya sosialisasi tersebut pengelolaan keuangan Badan Usaha Milik Desa (BUMDes) berdasarkan SAK ETAP di Desa Ayumolingo Kecamatan Pulubala Kabupaten Gorontalo maka peserta lebih memahami penjelasan dan petunjuk- petunjuk riil lapangan yang disampaikan oleh narasumber atau pemateri dalam meningkatkan keterampilan untuk mengelola keuangan pada Badan Usaha Milik Desa (BUMDes) di Desa Ayumolingo Kecamatan Pulubala Kabupaten Gorontalo kearah yang lebih baik dan lebih professional. Dengan adanya sosialisasi tersebut tentang pengelolaan keuangan Badan Usaha Milik Desa (BUMDes) berdasarkan SAK ETAP di Desa Ayumolingo Kecamatan Pulubala Kabupaten Gorontalo dapat terbantu dalam mengelola keuangan BUMDes sehingga pengelolaan keuangan tersebut dapat lebih transparan dalam menjalakan usahanya.

Sosialisasi dalam pengabdian ini pemateri menjelaskan standar yang berlaku dalam menyusun laporan keuangan BUMDes. Pada sesi ini peserta dijelaskan standar akuntansi keuangan berdasarkan SAK ETAP. Sesi kedua, peserta diberikan penjelasan cara mencatat jurnal ketika ada transaksi. dan sesi ketiga peserta juga diberikan contoh kasus dan cara membuat jurnalnya serta memposting kedalam buku besar. Sesi empat, pada sesi ini diisi dengan tanya jawab antara tim pengabdian dengan para pengelola keuangan BUMDes. Para peserta diberikan waktu 30 menit untuk berdiskusi serta menyampaikan kesulitan yang dialami. Sesi lima, mempraktikan membuat laporan keuangan BUMDes sesuai dengan standar yang berlaku. Peserta membuat laporan keuangan desa dan tim pengabdi memantau serta membantu jika ada kesulitan yang dialami peserta.

Hal yang menjadi catatan adalah pentingnya kerjasama antara institusi dengan desa binaan, karena untuk jangka panjangnya tidak hanya sosialisasi saja akan tetapi pendampingan secara berkelanjutan. Keberhasilan program pelatihan ini diukur dengan parameter: 1 . Melakukan input data transaksi hingga mampu menyusun laporan keuangan 2. Meningkatnya kualitas informasi bagi masyarakat sebagai dasar evaluasi kinerja pengelolaan keuangan BUMDes di Desa Ayumolingo Kecamatan Pulubala Kabupaten Gorontalo 


\section{Diskusi}

Sejalan dengan pentingnya desa dan pemerintahan desa yang diharapkan dapat mengatur dan mengurus kepentingan masyarakat hukum setempat berdasarkan asal usul dan istiadat, maka pemerintah desa dituntut untuk melakukan manajemen keuangan desa secara maksimal agar setiap sumber daya yang ada dikelola dengan baik agar mempunyai manfaat kepada masyarakat. Mengenai pentingnya manajemen keuangan bagi setiap organisasi dimaksudkan melakukan pengalokasian dana perusahaan secara efisien. Bambang (2002) menyatakan bahwa secara keseluruhan aktivitas perusahaan yang berhubungan dengan usaha mendapatkan dana yang diperlukan dengan biaya yang minimal dan syarat-syarat yang paling menguntungkan beserta usaha untuk menggunakan dana tersebut seefisien mungkin manajemen terhadap fungsi-fungsi keuangan.

Sejalan dengan pentingnya manajemen keuangan juga sesuai dengan pendapat Husnan (2002) yang menyatakan bahwa manajemen keuangan merupakan segala aktivitas yang berhubungan dengan perolehan, pendanaan serta pengelolaan aktiva dengan tujuan menyeluruh. Demikian juga pendapat Keown (2001) bagaimana bisnis yang diselenggarakan dapat memperoleh dana, bagaimana mereka mendapatkan dana, bagaimana penggunaan mereka serta bagaimana bisnis profit didistribusikan.

Demikian juga pendapat Macey (1998) manajemen keuangan sebagai usaha untuk dapat menyediakan uang serta menggunakan uang untuk mendapat atau juga memperoleh aktiva. Michel dan Shaked (1984) yang menyatakan bahwa manajemen keuangan merupakan suatu proses dalam kegiatan keuangan perusahaan yang berhubungan dengan upaya untuk mendapatkan dana perusahaan serta meminimalkan biaya perusahaan dan juga upaya pengelolaan keuangan suatu badan usaha atau organisasi untuk dapat mencapai tujuan keuangan yang telah ditetapkan. Dubofsky dan Varadarajan (1987) secara sederhana menyatakan bahwa manajemen keuangan merupakan hal yang sangat penting dalam setiap organisasi karena tujuannya adalah agar nilai yang dimiliki oleh perusahaan bisa maksimal dan dapat memberikan nilai tambah dari segi finansial atau asset pada perusahaan. Ruang lingkup manajemen di bidang keuangan adalah keputusan investasi, pengelolaan aset dan keputusan pendanaan.

Badan usaha milik desa (BUMDes) didirikan dengan maksud agar setiap sentra ekonomi yang ada di desa mempunyai wadah untuk pengelolaannya. Selain itu dengan pendirian BUMDes maka tujuan yang diharapkan adalah dapat menyediakan berbagai kebutuhan pokok masyarakat dalam melaksanakan aktivitas-aktivitas ekonomi sehari-hari (Permendes Nomor 4 tahun 2015).

Sejalan dengan pentingnya pendirian BUMDes, maka pengelolaannya harus dimaksimalkan agar dapat memberi dampak kepada masyarakat terutama kepada manajemen keuangan Badan Usaha Milik Desa (BUMDes). Di dalam Standar Akuntansi Keuangan (2012) dijelaskan beberapa manajemen keuangan yang penting ialah pembuatan laporan laba rugi, laporan perubahan modal, laporan neraca yang meliputi harta, modal dan utang serta laporan arus kas (Harrison dan Horngren, 1995).

\section{Kesimpulan}

Berdasarkan hasil kegiatan pengabdian yang dilaksanakan di Desa Ayumolingo Kecamatan Pulubala Kabupaten Gorontalo khusunya pada BUMDes, disimpulkan bahwa 
manajemen keuangan BUMDes Rahmat khususnya dalam pelaporan keuangan masih bersifat tradisional dan hanya berakhir pada tahap pencatatan.

Penting bagi pengelola BUMDes untuk memaksimalkan usahanya agar dapat memberikan layanan kepada masyarakat secara berkualitas. Serta bagi pengelola BUMDes untuk memahami dan menerapkan model pelaporan keuangan berdasarkan SAK-ETAP, sehingga manajemen keuangan yang dilakukan tidak hanya berakhir pada proses pencatatan transaksi dengan perkiraan penerimaan dan pengeluaran.

\section{Pengakuan/Acknowledgements}

Terima kasih kepada seluruh pihak yang telah memberikan kontribusi baik secara langsung maupun tidak langsung sehingga kegiatan pengabdian ini dapat terlaksana dengan baik. Terima kasih kepada Kepala Desa Ayumolingo Kecamatan Pulubala Kabupaten Gorontalo yang telah memberikan kesempatan bagi pengabdi untuk melaksanakan kegiatan pengabdian ini, dan teristimewa kepada pengelola BUMDes di Desa Ayumolingo yang telah bersedia menjadi peserta pengabdian. Semoga apa yang telah disampaikan dalam kegiatan pengabdian ini dapat memberikan manfaat bagi pengelola BUMDes dalam mengelola usahanya.

\section{Daftar Referensi}

Ariantini, N. L. G., Zukhri, A., \& Meitriana, M. A. (2014). Penerapan SAK ETAP dalam Penyusunan Laporan Keuangan Pada Koperasi Simpan Pinjam Lambing Sejahtera Mandiri. 4(1).

Dubofsky, P., \& Varadarajan, P. R. (1987). Diversification And measure of Performance Additional Empirical Evidence. Academy of Management Journal, 30(3), 597-608.

Epstein, \& Manzoni. (1998). Implementing Corporate Strategy : From Tableaux De Board To Balanced Scorecards. European Management Journal, 2, 190-203.

Horngren, C. T., \& Jr, W. T. H. (2007). Accounting. Erlangga.

Ikatan Akuntan Indonesia (IAI). (2015). Pernyataan Standar Akuntansi Keuangan Ikatan Akuntansi Indonesia, 2009, Standard Akuntansi Keuangan, PSAK No. 1 : Penyajian Laporan Keuangan. Salemba Empat.

Keown, A. J. (2001). Dasar-Dasar Manajeme Keuangan. Salemba Empat.

Knight, R., \& Bertoneche, M. (2001). Financial Performance. Butterworth Heinemann.

Macey, J. (1998). Measuring the Effectiviness of Different Corporate Governance Systems : Toward A More Scientific Approach. Bank of America Journal of Applied Corporate Finance, 63(2), 16-25.

Meigs, M. \&, Bettner, \& Whittington. (1996). Accounting The Basis For Business Decisions. Mcgraw-Hill College.

Michel, A., \& Shaked, I. (1984). Does Business Diversification Affect Performance? Financial Management, 13(4), 18-25.

Riyanto, B. (2002). Dasar-Dasar Pembelanjaan Edisi 4. BPFE. 
Suad, H. (2002). Manajemen Keuangan Teori Dan Praktek. Yayasan Badan Penerbit Gajah Mada Yogyakarta. 